\title{
Grotesco: un hito en la travesía de la novela hispanoamericana
}

\author{
Grotesque: A Landmark in the Hispanic \\ Amercan's Novel Crossing \\ Martha Elena Munguía Zatarain \\ Instituto de Investigaciones Lingüístico-Literarias \\ Universidad Veracruzana, Xalapa, México \\ marthamunguiaz@gmail.com \\ ORCID: https://orcid.org/0000-0002-8608-0616
}

ISSN-OI85-4259; e-ISSN: 2007-9176

DoI: http://dx.doi.org/I0.28928/ri/892020/atc4/munguiazatarainme

\begin{abstract}
Resumen:
La tarea de reconstruir la historia de la literatura hispanoamericana sigue siendo un pendiente para los estudiosos, a pesar de la gran cantidad de manuales y recuentos que ya existen. En el presente ensayo se revisan algunos de los problemas que han obstaculizado un desarrollo más o menos satisfactorio en este campo. Se reconoce la carencia de estudios críticos de obras esenciales y la falta de lecturas con nuevas perspectivas de análisis que se fundamenten en la estética. Se propone empezar por restablecer el nexo de la novela con las antiguas tradiciones populares, de carácter oral, que han marcado el perfil de la escritura novelesca, y se ejemplifica con la revisión de dos obras disímbolas, pero en las que se ven con toda claridad las huellas de la estética grotesca en su configuración: Cien años de soledad de García Márquez y Patas de perro de Carlos Droguett.
\end{abstract}

Palabras clave: modernidad, oralidad, historia literaria, estética, tradición

\begin{abstract}
:
In spite of the great amount of manuals and monographies already existing, reconstructing the History of Hispanic American Literature is still a pending task. The aim of this paper is to review some of the problems that have being hindering a reasonably satisfying progress in this field, although we have to recognize the lack of new and different approaches based in Aesthetics. At the same time, we propose to start reestablishing the link of the novel with ancient popular traditions of oral character which have determined the profile of novel writing and are exemplified with the review of two works of very different character in the configuration of which, however, the trace of a grotesque Aesthetics is evident: A Hundred Years of Solitude by García Márquez, and Dog Feet by Carlos Droguett.
\end{abstract}

Keywords: modernity, orality, literary history, Aesthetics, tradition

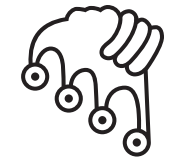

IZTAPALAPA

Agua sobre lajas 
$L$ os estudios de la literatura hispanoamericana enfrentan un sinfín de retos actuales en todos los ámbitos de su desarrollo: teoría, crítica e historia literaria. Desde hace algunos años se ha debatido acerca de la existencia o no de una verdadera teoría de la literatura, rigurosa y pertinente, que dé razón de la complejidad del fenómeno literario en este continente y a pesar de los esfuerzos históricos por construirla, tal vez sea posible encontrar todavía negaciones e incluso críticos que hablen de fracasos en este terreno. ${ }^{1} \mathrm{Si}$ nos adentramos en el problema de la historia, las cosas son todavía más complicadas pues al parecer se abandonó el impulso de construir historias de la literatura globales y abarcadoras y se ha optado por la frecuente organización de tomos colectivos con capítulos a cargo de distintos autores en los que cada quien escribe según criterios diversos con lo que obtenemos recuentos parciales, visiones fragmentarias. En el mejor de los casos se intenta historiar la literatura de un país.

Existe, sin duda, un profundo descontento entre algunos académicos por la situación de abandono. Se muestran preocupados por revivir y devolver la fuerza a la tradición estudiosa de América Latina. De ahí que en los últimos años hayan proliferado las propuestas de revisión de los criterios tradicionales con los que se historiaba la literatura. En estas revisiones críticas ha merecido especial atención el problema de la periodización. Este, en efecto, es un asunto medular que reclama renovar los instrumentos y la relectura desprejuiciada de nuestras obras magistrales si queremos restituir a la historia literaria su papel central.

1 Véase la explicación que apuntaba Antonio Cornejo Polar en la década del noventa sobre este punto, porque fue uno de los principales impulsores de la construcción de un sólido andamiaje teórico para estudiar nuestra literatura y partió del reconocimiento de que difícilmente podría hablarse de éxito en la tarea de construir una teoría propiamente latinoamericana debido, precisamente, a que los esfuerzos que se orientaron a pensar en la literatura de este continente como si fuera una sola y no diversa, plural, heterogénea, lo que llevó al fracaso a muchos de los intentos encaminados en esa dirección (Cornejo, 1999). 
El presente ensayo busca conectarse con esa línea de investigación que intenta releer las obras de nuestro subcontinente desde criterios estéticos. En esta larga y compleja historia resulta esencial tener en cuenta un problema central en la literatura latinoamericana: la relación entre oralidad y escritura, pues ha definido trayectos artísticos. Una de las vertientes fructíferas en esta línea tiene que ver con la estética de lo grotesco, una estética universal, antigua y sumamente productiva que, sin embargo, ha sido pasada por alto en las historias literarias. Con este fin estableceré unas coordenadas esenciales para hacer la revisión de dos obras divergentes de la literatura hispanoamericana y que, sin embargo, forman parte de una misma línea de desarrollo: Cien años de soledad y Patas de perro. Evidentemente, el objeto de este trabajo involucra varios problemas, como el de la periodización, el del género novelesco en América Latina y las muy complejas relaciones entre lo culto y lo popular, lo oral y lo escrito. Es imposible en este trabajo resolver todos estos problemas, pero sí vale la pena detenerse a apuntar algunas líneas que me permitan transitar por el cauce que intento trazar.

No me detendré aquí a revisar las formas en las que ha procedido la historiografía literaria dominante porque ese trabajo ya lo han hecho otros antes, y de manera muy clara, como García-Bedoya, Roberto González Echevarría, ${ }^{2}$ o como Schmidth-Welle, quien se ocupa también de revisar los conflictos de la periodización tradicional y que ha trasplantado las categorías europeas para organizar el material latinoamericano, se detiene a explicar las repercusiones que este modelo interpretativo ha tenido, como el hecho de ignorar los sistemas literarios no cultos (populares e indígenas),y afirma:"Toda literatura que no se afilia a las categorías de la historia literaria europea simplemente no puede existir -o se reduce a un objeto de estudio folclórico y antropológico" (Schmidth-Welle, 2018:107) ${ }^{3}$.Y, en efecto, esta carencia es palpable en la mayor parte de las reconstrucciones históricas nacionales, pues se ha dejado a otras disciplinas el estudio de las formas de imaginación de las comunidades orales.

Véase en particular su texto "Breve historia de la historia de la literatura latinoamericana” (González, 2006).

3 Predomina también en las historias literarias la imposición de periodos a partir de los acontecimientos políticos y sociales, aunque, como apunta Eva Kushner:"No se trata en modo alguno de negar los múltiples lazos que existen entre los grandes acontecimientos políticos o las instituciones gubernamentales de una época y una sociedad determinadas y la producción literaria correspondiente, sino de impugnar que haya una coincidencia absoluta entre sus articulaciones cronológicas y que la primera serie tenga un valor heurístico para la segunda" (Kushner, 1994ः 174). 
He aquí el gran reto para los estudiosos de la historia literaria aunque, me temo, nos sigue faltando el arrojo para lanzar nuevas hipótesis que nos abran caminos por donde transitar. Ahora bien, para enfrentar con cierta solvencia esta tarea es preciso resolver antes una serie de problemas que nos plantea el material que vamos a historiar, por ejemplo, la ausencia de trabajos críticos de obras esenciales que han permanecido en los márgenes de la cultura; en otras palabras, el corpus sigue siendo provisional y precario, justamente por ese desdén hacia las manifestaciones que se han clasificado como subproductos artísticos. Pero incluso las obras clásicas que han formado parte del canon aguardan nuevos enfoques críticos que salgan de las rutas trazadas por la convención. ${ }^{4}$ Ante todo, hace falta dejar de pensar en la literatura latinoamericana como una sola línea de desarrollo homogénea, para, como lo plantea García-Bedoya, "asumir la pluralidad de sistemas que conforman nuestras literaturas y estudiarlas como totalidades complejas, contradictorias, articuladas en un curso histórico común" (García-Bedoya, 2018:63).

Otro aspecto que es preciso tener en cuenta es la tremenda laguna que debe ser resuelta por la disciplina de la poética histórica para abonar en el camino hacia reconstrucciones históricas más justas: la revisión crítica de algunos géneros literarios, especialmente el novelesco, género inasible, inestable, multifacético, en incesante proceso de transformación, difícil de deslindar de otras formas colindantes con él. El estudio histórico de la novela hispanoamericana ha sido, en el mejor de los casos, un recuento de anécdotas agrupadas en romanticismo, realismo, naturalismo, criollismo o novela de la tierra, real maravilloso, realismo mágico, etc., donde una escuela supera a la anterior. A veces se organiza el material, sobre todo en el siglo $\mathrm{xx}$, a partir de categorías meramente temáticas, como novela de la selva, novela de la dictadura, novela de la Revolución mexicana y muchas otras de este tipo.

Tampoco podemos hallar la solución en el traslado acrítico de las vertientes que ha reconocido Bajtín, por ejemplo, para la novela europea. No es mucho lo que avanzamos clasificando como novela carnavalesca o novela polifónica a algunas, descalificando a otras como monológicas. $Y$ no es que haya que prescindir de los descubrimientos importantes del teórico ruso para pensar la novela, pero no los podemos "aplicar" sin más a materiales generados en otros contextos, con otra

4 Pienso ahora, a modo de ejemplo, en la lectura grave y solemne que han recibido una gran cantidad de textos que están atravesados por el espíritu de la risa, en sus distintas tonalidades, que van desde la ironía, pasando por la parodia, hasta lo grotesco, porque los críticos han decidido cerrarse a escuchar las resonancias que hay en ellos y han optado por recuperar el lado serio, heroico, sentimental, que ha sido más valioso en los marcos de la cultura dominante. 
tradición a sus espaldas. En todo caso, estas aportaciones tienen que funcionar como posibles puntos de partida que nos lleven por otras rutas o, en los términos en los que plantea Françoise Perus, hay que entender su valor epistemológico y metodológico para tratar de indagar las "vías artísticas concretas por las cuales la narrativa hispanoamericana ha intentado dar cabida a la heterogeneidad cultural, al plurilingüismo o la heteroglosia propias del subcontinente americano" (Perus, I998: 29). Si retomo la categoría artística de grotesco para este ensayo, es justamente en este espíritu de aprovechar el legado de la teoría y la crítica occidental, pero buscando no perder de vista nuestras peculiaridades culturales.

Por último, no ignoro que se han puesto ya objeciones al estudio histórico por géneros o por obras particulares pues es una manera de perder la visión general y abarcadora del fenómeno literario; pero tampoco podemos desatender las diferencias radicales entre cada género, ya que, como muy bien lo observó González Echevarría, la narrativa y la lírica "do not follow the same historical path, nor do they change at the same rhytm; hence I think it is a mistake to write literary history as if all genres moved together in the same direction like a vast river" (González Echevarría, 2004: 289). Y dado que nos faltan estudios de los trayectos que cada género ha seguido, resulta no solo legítimo sino necesario encarar esta tarea. Me parece que la novela es una pieza fundamental que ha quedado suelta en el gran engranaje de la historia literaria, pues con demasiada frecuencia se ha resuelto que fue una importación tardía de Europa y que siempre de manera rezagada fue desarrollándose a la sombra de los descubrimientos artísticos hechos del otro lado del Atlántico.

Ha habido valiosos intentos por desentrañar las fuentes de donde ha bebido la novela, más allá de los caminos trillados, para entender el perfil que ha adquirido; una de las propuestas importantes de los tiempos actuales es la de González Echevarría, quien analiza las huellas que dejaron en los relatos otras fuentes discursivas extraliterarias en el proceso de construir el archivo que ha creado la novela moderna. Entre estas fuentes destacan los diarios de viajes de los exploradores científicos en los que quedaron asentados testimonios de lo que observaron en la naturaleza americana; otra fuente son los estudios antropológicos que revelaron la importancia del mito en las comunidades originarias. Tampoco se olvida de reconocer la presencia del discurso notarial, del imputado que se defiende ante las instancias judiciales, que fue fundamental en la creación de la novela picaresca y que ejerció una influencia muy importante en el periodo colonial (González Echevarría, 20II).

Con todo y lo productivas que resultan sus sugerencias para obligarnos a pensar de otra manera el proceso de conformación del género novelesco en Hispanoamérica, es muy claro que hay una serie de problemas e inconsistencias en la propuesta. 
Destaca la omisión de la fundamental presencia configuradora de las formas orales, no solo en términos lingüísticos, sino también, y sobre todo, en el plano de la imaginación artística. ${ }^{5}$ Sin tener en cuenta las huellas del pensamiento oral tradicional no es mucho lo que se puede avanzar en el reconocimiento del perfil de cientos de relatos esenciales para entender la cultura literaria latinoamericana. Resulta muy revelador cómo a pesar de las constantes confesiones de escritores importantes de América Latina, a veces de forma lúdica, a veces con toda la seriedad, de que hallaron un tono y un estilo para contar volviendo a las reminiscencias de los antiguos relatores orales, abuelas, tías, un inventado "tío Celerino", esto no ha sido tomado en cuenta por la crítica y mucho menos por la historiografía literaria. Al parecer, la crítica casi siempre se ha empecinado en encontrar las fuentes escritas de las obras literarias, entendidas como relaciones de influencias y hemos perdido así gran parte de los gérmenes de la novela y del cuento en estas latitudes. Por supuesto, no se trata de negar el peso cultural de los textos escritos, relatos de viajeros, informes antropológicos, obras como Facundo, que sin duda han sido muy significativos, pero nos falta recuperar esa otra faceta de importancia crucial que le ha dado un perfil particular al desarrollo de la novela hispanoamericana.

\section{Huellas del pensamiento oral en la novela moderna: la estética de lo grotesco}

Si el siglo xx significó el reconocimiento universal de la calidad de la novela latinoamericana, no quiere esto decir que hasta ese momento se haya llegado a la cristalización de aspiraciones estéticas no alcanzadas antes. Tampoco se puede remitir el tono, la orientación y los aciertos formales a una tardía pero exitosa digestión de los hallazgos hechos en Europa. Estamos ante una trayectoria sinuosa y compleja en la que el género se ha debatido para ir conquistando formas expresivas, puntos de enunciación particulares, soluciones artísticas a los problemas de la pluralidad

5 Hay importantes trabajos críticos que avanzaron en el camino de ir revelando la innegable presencia de la oralidad en la escritura narrativa, como es el caso de La comarca oral del venezolano Carlos Pacheco (1992). Con todo y la deuda que tenemos con él, no sigo aquí su trayecto porque optó por pensar el problema en términos de ficcionalización de la oralidad, con lo que, desde mi punto de vista, se quedó en observaciones de carácter formal y no alcanzó a ver el problema en su amplia dimensión estética, que va mucho más allá de la mera estructura lingüística de los relatos. 
cultural que nos caracteriza. ${ }^{6}$ A continuación me voy a referir solo a una de las huellas que ha dejado el pensamiento oral en la configuración de la novela moderna y que, desde mi punto de vista, podría funcionar como uno de los ejes alrededor del cual empezáramos a estudiar un corpus importante de novelas desde una perspectiva histórica no cronológica, sino desde el horizonte de la estética.

Es bastante evidente que en América Latina están más frescas las heridas de la pugna entre tradición y modernidad que en otros ámbitos de Occidente, y en esta feroz pugna se han gestado las grandes obras de los maestros reconocidos universalmente: no puede dejar de apreciarse el hecho irrefutable de que no ha habido sobre la tierra escritores más modernos y cosmopolitas que Borges o Cortázar, a la vez que hemos tenido autores que han creado insólitas imágenes artísticas partiendo de las profundas raíces de la visión popular, como Juan Rulfo o García Márquez.

Para darle cuerpo a esta pugna histórica en la cultura literaria latinoamericana, tal vez pueda resultar fructífero recuperar la idea que José María Arguedas dejó plasmada en su diario de moribundo que antecede a su última novela incompleta, El zorro de arriba y el zorro de abajo, sobre los dos tipos de escritores que ha habido en América Latina: los profesionales y los que él llamó, un tanto en tono de juego, provinciales. Se refería justamente a esas dos formas contrastantes de concebir la literatura, dos visiones de mundo, y aunque no lo mencione el escritor, estas actitudes han marcado las obras que se han escrito:

Yo no soy escritor profesional, Juan [Rulfo] no es escritor profesional, ese García Márquez no es escritor profesional. ¡No es profesión escribir novelas y poesías! $\mathrm{O}$ yo, con experiencia nacional, que en ciertos resquicios sigue siendo provincial, entiendo provincialmente el sentido de esta palabra oficio como una técnica que se ha aprendido y se ejerce específicamente, orondamente para ganar plata. Soy en ese sentido un escritor provincial [...] Escribimos por amor, por goce y por necesidad, no por oficio. Eso de planear una novela pensando en que con su venta se ha de ganar honorarios, me parece cosa de gente muy metida en las especializaciones. Yo vivo para escribir, y creo que hay que vivir desincondicionalmente para interpretar el caos y el orden (Arguedas, 1992: 18).

6 Ya Mario Valdés en la introducción al monumental estudio que coordinó sobre la cultura literaria en América Latina apuntaba que la enorme riqueza proviene al menos de tres tradiciones: la amerindia, especialmente en Mesoamérica y la región andina; la europea, español y portugués, además de las culturas africanas en Brasil y en la región del Caribe (Valdés, 2004: XVII). 
Claro que Arguedas estiraba al máximo la liga para entender estas dos posiciones vitales y artísticas al referir una al interés económico y la otra a la pasión. No hay duda de que escritores como García Márquez ganaron considerables cantidades de dinero por su obra y que, del otro lado, jamás podríamos negar la pasión de toda una vida en escritores como Cortázar o Borges, más allá de lo que pudiera reportarles en términos monetarios. Tampoco se trata de categorías absolutas. Son solo una guía orientadora para enfrentar el caótico panorama que nos presenta la modernidad.

El listado de escritores profesionales que elaboró Arguedas frente a los provinciales es indicador de cómo entendía estas dos actitudes: "Vallejo no era profesional, Neruda es profesional; Juan Rulfo no es profesional. ¿Es profesional García Márquez? ¿Le gustaría que le llamaran novelista profesional? Puede decirse que Molière era profesional, pero no Cervantes" (Arguedas, 1992: 19). Julio Cortázar, Mario Vargas Llosa, ${ }^{7}$ Carlos Fuentes eran profesionales y por nuestra parte podríamos continuar la lista diciendo, por ejemplo, que Borges fue, sin ninguna duda, un escritor profesional.

Ahora, después de estos breves trazos de reconocimiento de dos grandes y, sin duda, problemáticas vertientes por donde han corrido los trayectos literarios en Hispanoamérica, me detengo en algunos rasgos de los llamados escritores provinciales, entendiéndolo como aquellos que no se han despojado de su pertenencia radical a la tierra, que no ven el mundo popular con el lente folclorizante del color local sino como una fuente viva de acumulación y renovación de tradiciones milenarias. Estos escritores han apostado por reencontrar el vínculo de la palabra artística con la palabra popular en su sonoridad y en su profunda vocación de diálogo. La concepción del tiempo en la obra de estos autores no es puramente formal; podemos encontrar un profundo trabajo con el tiempo mítico de la circularidad a la vez que una aguda conciencia del fluir del tiempo histórico. Escritores como García Márquez, Juan Rulfo, Arguedas, Guimaraes Rosa o, más recientemente, Fernando del Paso, lograron fusionar en una visión estética el legado de la tradición popular con los hallazgos artísticos de la tradición culta. Como consecuencia de ello, en la obra de estos escritores la risa juega un papel fundamental, orquestadora de la totalidad del sentido, una risa que se escucha fuerte, que mantiene los vínculos con

7 A pesar de todas las diferencias que podrían reconocerse entre la obra de Arguedas y la de Carlos Droguett, este llegó a decir de Vargas Llosa, en un tono que recuerda las reflexiones de Arguedas, que era de los escritores "masturbadores", "porque escriben con estilo, pero sin lograr que el texto rezume sufrimiento, angustia, violencia, dolor, muerte" (citado en Meruane, 2016: 5). 
la fiesta y la vida, una risa lejana a la degradación y al mero sarcasmo o a la ironía y mucho más celebratoria. Si seguimos la pista a la permanencia de la estética de lo grotesco, en tanto estética nacida y crecida en el seno de la visión oral tradicional del mundo, tal vez podamos acercarnos a precisar uno de los perfiles de la novela hispanoamericana moderna.

Echar mano de la noción de grotesco como categoría de análisis estético para cierta vertiente de la literatura latinoamericana puede resultar un tanto perturbador, así que voy a intentar justificarlo y poner con claridad los límites de lo que se entenderá por ese término, aunque sea del modo más resumido posible: creo que a estas alturas ya nadie puede confundir los adjetivos feo, monstruoso, con el de grotesco, pues sin bien por el uso cotidiano, familiar, pueden en algunos contextos ser colindantes, no lo son desde el punto de vista de los ya largos estudios de estética. Lo grotesco alude a la imaginación artística de corte tradicional antiguo, como lo estudió Bajtín detenidamente en su libro sobre la obra de Rabelais. En una compleja y distendida perspectiva histórica, Bajtín caracterizó lo grotesco, entre otras cosas, por una concepción cíclica del tiempo; un desconocimiento de las fronteras entre mundo vegetal, animal, humano, mineral, vida y muerte; una desbordada imaginación de abundancia espacial, corporal; un pleno sentido regenerador en la satisfacción de las necesidades corporales, como beber, comer, defecar, la sexualidad y una mirada risueña y jocosa ante la vida (Bajtín, 1988, en especial los dos primeros capítulos). Esta forma de imaginación ha sido universalmente compartida; hay una serie de rasgos muy claros en las culturas latinoamericanas que permiten hablar de grotesco en estos términos; aunque también es innegable que esta visión de mundo ha sido expulsada de la alta cultura y difícilmente hallaremos versiones escritas de auténtico grotesco de raigambre popular. Con todo, sí quedan muestras de supervivencia de esta imaginación relegadas en la producción de "artesanía" (lo que no entra en la categoría de arte, como los alebrijes mexicanos), en rituales colectivos y, en particular, en las formas orales de transmisión de las tradiciones (cuentos, leyendas, cantos). ${ }^{8}$

8 No se puede ignorar que Bajtín planteó la pervivencia de la imaginación tradicional grotesca a través de las imágenes creadas en el carnaval antiguo y renacentista y el trabajo estético que hicieron los autores que forjaron lo que él llamó la literatura carnavalizada. Sus análisis fueron sumamente reveladores para entender el proceso de conformación de una línea artística de la novela europea. Me parece, sin embargo, que no es exactamente ese el camino que tomó en América Latina la introducción de lo grotesco en la narrativa culta, sino en el trabajo que hicieron los autores con la oralidad y en la recreación de esa imaginación popular, arrojada a los márgenes de la cultura. Tampoco se trata de negar el fructífero diálogo con la tradición europea en la conformación de 
Por esta razón es que la oralidad constituye un indicio importante en el proyecto artístico de algunas obras narrativas de América Latina, de su nexo con las tradiciones populares antiguas, de carácter grotesco.

Ahora bien, como apuntaba antes, no se debe olvidar que las sociedades latinoamericanas se han forjado en una fuerte tensión entre modernidad y tradición y la novela no ha sido ajena a esta pugna, porque una vertiente de su escritura fue sumamente crítica con las formas en las que esa modernidad se imponía en estos territorios, como un proceso depredador que atentaba contra los valores humanos. Y no es que se halle en estas obras una reivindicación del mundo primitivo o feudal, sino que encuentran en la imaginación tradicional popular una impugnación del mercantilismo, de la insensibilidad ante los dolores humanos que significó la modernidad importada de Europa y Estados Unidos. En este debate se deja muy clara la representación artística del tiempo histórico. La modernidad ha sido la época de las masas, esto es, la construcción de una cultura desde el poder que ha ido devorando los restos de las formas de vida tradicionales y las ha mezclado con expresiones de la alta cultura, refinada, escrita, ligada a la academia y a la renovación. La nueva cultura, erigida en el intersticio de los caminos de lo culto y lo popular, tiende a la universalidad, al borramiento de fronteras y de diferencias regionales.

Muchos de los rasgos que se han reconocido como característicos del realismo mágico y que se lograron identificar en Cien años de soledad están estrechamente ligados a la universal estética de lo grotesco que en estos momentos de la modernidad tiene lazos claros con la visión oral del mundo, pero también con una muy fuerte tradición escrita, culta. ${ }^{9}$ Entre esta novela cumbre de la literatura hispanoameri-

la cultura letrada latinoamericana, de tal suerte que el camino crítico debe ser doble en este lado del Atlántico, recuperando, por un lado los instrumentos que ha desarrollado la tradición teórica de otros ámbitos y, por otro, buscando las relaciones particulares de la literatura latinoamericana con su cultura y su propia tradición.

La abundante producción de trabajos críticos que motivó esta novela impide un acercamiento a las muy diversas valoraciones que de ella se han formulado, ni es mi intención la exhaustividad. Pero es un hecho que prácticamente ninguno de los críticos, aun los más connotados, como Ángel Rama o Vargas Llosa, llegaron a establecer la relación de esta novela con la imaginación grotesca y prefirieron analizarla como una narrativa en la que se naturalizaba lo maravilloso popular, de ahí su colindancia con lo fantástico. Véase, por ejemplo el muy interesante estudio de Rama, La narrativa de Gabriel García Márquez. Edificación de un arte nacional y popular. Es el caso del estudio que emprende también Pozuelo Yvancos sobre la novela. Llega a anotar una serie de rasgos que están claramente emparentados con la imaginación grotesca: "La evidencia estilística más sobresaliente desde su comienzo es que en esta novela se transita fácilmente desde el 
cana y Gargantúa de Rabelais se tiende un puente sutil pero innegable que resulta sumamente esclarecedor de la estética grotesca renovada en la que está escrita Cien años de soledad. Y este nexo no solo se puede identificar a partir de las propias declaraciones de Gabriel García Márquez de haber sido lector de Rabelais, sino que en la propia novela se siembra la referencia explícita: "El pueblo había llegado a tales extremos de inactividad, que cuando Gabriel ganó el concurso y se fue a París con dos mudas de ropa, un par de zapatos y las obras completas de Rabelais, tuvo que hacer señas al maquinista para que el tren se detuviera a recogerlo" (García Márquez, $2007: 456){ }^{10}$ No ha pasado inadvertido el guiño de que ese personaje del final de los tiempos de Macondo es el propio autor ficcionalizado, aunque este reconocimiento casi siempre se queda en el mero nivel anecdótico.

Vale la pena aclarar que un escritor como García Márquez no busca ligar su estética con el grotesco romántico de carácter sombrío y tenebroso, sino con la comicidad y la ambivalencia antigua que, como mencionaba antes también floreció entre los pueblos hispanoamericanos. ${ }^{11}$ Se puede afirmar que el eje alrededor del cual gira la entera composición poética de Cien años de soledad es el de la estética de lo grotesco: ahí está el mundo como algo inconmensurable, lleno de sorpresas y de inventos fabulosos, como el hielo, ahí están los seres que viven hasta 200 años, como Francisco el Hombre, el trotamundos que llegaba a Macondo a divulgar noticias en sus cantos, y ahí está la presencia descomunal de José Arcadio Buendía, el hijo, que un día se fue con los gitanos y volvió a la casa paterna después de darle sesenta y cinco veces la vuelta al mundo, lleno de tatuajes por todo el cuerpo, " $y$ su presencia daba la impresión trepidatoria de un sacudimiento sísmico” (García

mundo de los vivos al de los muertos, del animal al humano, de lo fantasmal o telúrico a lo racional; lo material se encuentra animado y lo humano muchas veces cosificado" (Pozuelo, 1993: 16I), pero al final decide explicarlo por la vía de lo maravilloso.

10

Desde 1995 Luis Beltrán había observado de manera muy aguda la cercanía entre Cien años de soledad y la novela de Rabelais. El crítico ofrece una lectura renovadora de la escritura de García Márquez en la minuciosa y atinada revisión que hace de las formas de asimilación del tiempo histórico, de la percepción folclórica de la temporalidad y la espacialidad de inhabituales dimensiones.

${ }^{11}$ En este punto, vale la pena deslindar por completo mi enfoque del trabajo clásico de Kayser sobre el grotesco (2010), ya que su perspectiva está marcada por el sentido romántico del término, en la dimensión aterradora, sombría del arte grotesco y pasa por alto la presencia de la risa festiva y celebratoria que le era inherente a la imaginación de carácter popular. Lo mismo ocurre con el manifiesto de Víctor Hugo que formula en el prólogo a su drama Cromwell (1989). 
Márquez, 2007ः IIO), dice el narrador. En esta obra, la sexualidad es desbordada al estilo del grotesco rabeleisiano: "En el calor de la fiesta exhibió sobre el mostrador su masculinidad inverosímil, enteramente tatuada con una maraña azul y roja de letreros en varios idiomas" (García Márquez, 2007: III). Cuando se casa con Rebeca "Los vecinos se asustaban con los gritos que despertaban a todo el barrio hasta ocho veces en una noche, $y$ hasta tres veces en la siesta, y rogaban que una pasión tan desaforada no fuera a perturbar la paz de los muertos" (García Márquez, 2007: 114). Obsérvese cómo se unen con toda naturalidad dos esferas que la cultura hegemónica ha separado tajantemente: la sexualidad desbordada y el mundo de los muertos. Es como si se insinuara, con estos guiños, que los muertos del cementerio no están tan radicalmente muertos, pues son susceptibles de ser perturbados por las expresiones extremas del placer mundano. La visión grotesca del mundo está estrechamente relacionada con la risa, una risa que no es admonitoria o sombría, sino que está ligada a la vida y a lo celebratorio, como puede advertirse en los ejemplos citados.

Es muy importante aclarar que la pervivencia de la visión grotesca del mundo no se resume en unas cuantas anécdotas en las que se manifiesta lo hiperbólico: es el eje de la organización del todo y anida en ella una profunda mirada crítica: Cien años de soledad va registrando el proceso de la entrada de la modernidad a Macondo con toda la violencia que entrañó y en este plano se convierte en una representación artística del desgarrador proceso que vivió América Latina. El narrador, jubiloso, también da muestra de las formas de resistencia del pueblo a las trampas que envolvía esa revolución ligada al supuesto progreso. Así, por ejemplo, cuenta sobre la llegada del cine, cómo se indignaron los espectadores "porque un personaje muerto y sepultado en una película, y por cuya desgracia se derramaron lágrimas de aflicción, reapareció vivo y convertido en árabe en la película siguiente. El público que pagaba dos centavos para compartir las vicisitudes de los personajes, no pudo soportar aquella burla inaudita y rompió la silletería" (García Márquez, 2007ः 257).

En este mirar con extrañeza las cosas y las marrullerías de la vida moderna, que tan comunes nos parecen hoy, la novela va desnudando alegremente el sentido profundo de la industrialización. Lo mismo ocurre con la llegada de los gramófonos que llevan a Macondo "las alegres matronas de Francia". Todo el pueblo va a la zona prohibida de la ciudad

[... y hasta se supo de señoras respetables que se disfrazaron de villanos para observar de cerca la novedad del gramófono, pero tanto y de tan cerca lo observaron, que muy pronto llegaron a la conclusión de que no era un molino de sortilegio, como todos pensaban y como las matronas decían, sino un truco mecánico que no podía 
compararse con algo tan conmovedor, tan humano y tan lleno de verdad cotidiana como una banda de músicos (García Márquez, 2007ः 258).

Justamente, esta mirada "llena de verdad cotidiana" es con la que el narrador va descubriendo el mundo que se abre a lo ajeno; registra paso a paso cómo deja de ser Macondo la aldea patriarcal en la que todos se reconocían, hasta la llegada plena de todos los inventos que caracteriza los tiempos modernos. $\mathrm{Y}$ no es gratuito que sean los gitanos quienes lleven, al principio, estos prodigios que deslumbran a los pobladores que reciben los inventos del siglo xx como máquinas milagrosas, con la mirada inocente y entusiasta de quien está arraigado en las tradiciones de la tierra. Después serán los viajeros provenientes del nuevo imperio, con su interés mercantil y depredador, quienes introduzcan estos cambios. Un día llega un sonriente $\mathrm{Mr}$. Herbert y prueba un racimo de bananos, lo que sellará la desgracia del pueblo con la invasión norteamericana y su visión clasista y jerarquizada; así lo sintetiza con sumo tino el coronel Aureliano Buendía: "Miren la vaina que nos hemos buscado, no más por invitar un gringo a comer guineo" (García Márquez, 2007: 262).

La novela es pletórica en todos los sentidos, en su temporalidad, en su espacialidad, en la duración de sus personajes, en la inacabable enumeración hiperbólica del narrador, en la eterna repetición cíclica de los nombres y de las desgracias que parecieran confirmar la percepción del tiempo de Úrsula, como si todo diera vueltas en redondo, las descomunales parrandas de Aureliano Segundo y sus competencias enloquecidas de quién es capaz de comer más, la reproducción inusitada del ganado por obra de la singular presencia de Petra Cotes, el empecinamiento de Amaranta y tantos episodios memorables sobre los que no voy a insistir. Esta visión de mundo plasmada en la novela está profundamente enraizada en la cultura popular. No se trata de un mero acudir al legado de la tradición culta y actualizar la visión de Rabelais a los parámetros de la modernidad. Los ejemplos podrían multiplicarse porque la novela en su totalidad está organizada desde la perspectiva y con el predominio de una risa ligada a la tierra que resiste la faceta deshumanizada de la industrialización moderna.

El estilo que logra García Márquez para registrar las voces distintas que pueblan este mundo contradictorio y en pugna resulta magistral y en ciertos momentos llega a desbordarse en este espíritu grotesco, como cuando la visión de Fernanda del Carpio penetra en la voz narradora y se expresa con toda su incesante profusión:

[... y era Fernanda que se paseaba por toda la casa doliéndose de que la hubieran educado como una reina para terminar de sirvienta en una casa de locos, con un 
marido holgazán, idólatra, libertino, que se acostaba bocarriba a esperar que le llovieran panes del cielo, mientras ella se destroncaba los riñones tratando de mantener a flote un hogar emparapetado con alfileres, donde había tanto que hacer, tanto que soportar y corregir desde que amanecía Dios hasta la hora de acostarse [... $]$ y que era el único mortal en ese pueblo de bastardos que no se sentía emberenjenado frente a dieciséis cubiertos, para que luego el adúltero de su marido dijera muerto de risa que tantas cucharas y tenedores, y tantos cuchillos y cucharitas no era cosa de cristianos, sino de ciempiés, [...] (García Márquez, 2007٪366).

Y así continúa con ese "abejorreo" en una larga parrafada en la que logra transmitir la indignación del personaje porque no halló nunca el modo de acomodar sus pretensiones señoriales y rancias en la casa de los Buendía; Fernanda se defiende, ataca, a la vez que puede sentirse la iluminación burlona del narrador de ese horizonte lleno de prejuicios y de un clasismo feudal. Y si el narrador retiene para sí la enunciación mientras deja que se cuele la voz de Fernanda es porque es el único modo de construir una representación jocosa del mundo interior de ese personaje que encarna precisamente los valores caducos de un tiempo que se perdió para siempre.

Si la literatura del llamado realismo mágico caló tan hondo que incluso propició la reproducción a veces acrítica del estilo forjado por los maestros de esta corriente $e^{12}$ se debe no solo a la apelación a la tradición humanística del Renacimiento, sino también y sobre todo a la propia historia cultural, popular y culta de América Latina que fue construyéndose poco a poco, y sobrevivía en los intersticios de la institución literaria. En los festejos de corte tradicional, en las costumbres de cada día, en el relato de las abuelas que contaban cuentos al amor de la lumbre, en los cantares populares de muchos pueblos de esta región es posible hallar la pervivencia de una visión grotesca de índole jocosa que ha marcado la vida de la región y de la que se han alimentado los escritores cultos.

Me voy a referir brevemente a otra novela de un autor hispanoamericano, de muy diferente cariz, para hacer evidente que no se trata de una opción individual de García Márquez, sino de un movimiento artístico más amplio y abarcador, de raíces profundas que ha involucrado una visión de mundo renovada y que ha sacudido las formas convencionales del discurso literario. A tal punto que se puede afirmar que la novela moderna en Hispanoamérica está signada en gran medida por la pervivencia

12 Me refiero a la larga lista de escritores que imitaron de manera superficial y repitieron sin creatividad los hallazgos artísticos de García Márquez, como Laura Esquivel o incluso la propia Isabel Allende. 
de estas huellas orales del pensamiento tradicional, ligado a una risa jocosa que se resuelve en una construcción de imágenes grotescas del mundo y de la vida. Así es Pedro Páramo; así son Noticias del Imperio y Palinuro de México de Fernando del Paso; ${ }^{13}$ así, El señor Presidente de Asturias; Domar a la divina garza de Sergio Pitol; Tengo miedo torero de Pedro Lemebel, entre muchas otras novelas fundamentales. Pero asomémonos un poco a una obra muy peculiar publicada en la década del sesenta en Chile, Patas de perro de Carlos Droguett (I912-1996), creada y leída en los márgenes del fragor del llamado boom de la literatura.

La mayor parte de los críticos afirma que se trata de una novela sin humor, acaso con una visión irónica o incluso sarcástica, en la que campea, en cambio, el escepticismo, la ira y el espíritu de lo trágico; y a estas lecturas no les falta razón si nos atenemos a la mera linealidad de lo anecdótico. Pero, sin duda, la novela es más que eso. Concebir la existencia de un niño marginal, que ha sido rechazado por su padre, que la madre no lo ha sabido defender porque nació con una deformidad que lo hace monstruoso a los ojos de la sociedad, pues de la cintura para abajo tiene patas de perro, supone el buceo en el horizonte de la anormalidad, de lo teratológico, que también, es obvio, puede merecer la interpretación metafórica o incluso alegórica de la marginación que sufre el diferente en las sociedades supuestamente civilizadas y democráticas; pero hay algo más en esta historia. Bobi es un niño insumiso que no está dispuesto a conceder, a ocultar su "deformidad" a los ojos reprobatorios de los demás, ni va a renunciar a su condición de mitad humano, mitad perro. Dice Ariel Dorfman: "La de Bobi es ante todo la historia de una persecución y de una búsqueda. Se lo acosa desde el momento en que nace: su familia, esa primera institución socializadora, que garantiza la continuación de la especie y que transmite los valores vigentes, es también la primera en iniciar el odio" (1970: 168).

El niño de trece años no vuelve a la escuela porque ahí también lo insultan y lo apalean; lo persiguen los policías; lo acosan los médicos que quieren experimentar en su cuerpo para devolverlo a la normalidad, lo encierran en el manicomio y en la perrera, hasta que decide escaparse para siempre.

Bobi fue adoptado por un hombre letrado, Carlos, el narrador que escribe la historia para olvidarla. Carlos es una fuente de amor hacia la criatura diferente, aunque en el fondo no logre comprenderlo y cometa errores garrafales, como comprarle unas botas para que oculte sus patas de perro, lo que provoca la indignación

13 He trabajado antes la forma en la que se expresa una estética grotesca ligada a la antigua tradición de la risa en Pedro Páramo de Rulfo y en Noticias del Imperio en mi libro La risa en la literatura mexicana (Munguía, 2012). 
del niño, o ir de barrio en barrio, de casa en casa, buscando siempre un sitio más acogedor, menos hostil, hasta llegar a concebir el proyecto de mudarse al campo, único lugar, cuando fueron de paseo, donde Bobi no recibió miradas escrutadoras o reprobatorias "-Nadie lo había mirado realmente, los ojos de los demás, si lo miraron, habían resbalado limpiamente por su cuerpo sin choques y sin adherencias" (Droguett, 2016: 108). El mundo rural, distanciado de las ciudades modernas, parece emerger como una esfera menos deshumanizada por menos prejuiciosa, aunque esta utopía no pueda llevarse a buen puerto. Bobi solo quería vivir su vida mitad humano mitad perro, quería comer carne cruda y se rehusaba a dormir en una cama. El niño halla entre los perros, en particular "aquel perro que trota junto a las alcantarillas, olisqueando tarros de basura y montones de desperdicios" (Droguett, 2016: 193), la comprensión y la solidaridad que no encontró entre los humanos. Y no necesito detenerme más en la anécdota para que se alcance a apreciar la elección de lo grotesco para configurar la imagen artística de la diferencia, de lo raro.

Bobi se conecta con la antigua tradición popular del humano híbrido que creó la imaginación grotesca - centauros, sirenas y demás figuras bien conocidas en Occidente-, pero en este caso se recrea la percepción negativa del fenómeno porque se resalta lo monstruoso, lo inarmónico y deja de verse la belleza que el niño sí percibe, ¿¿Por qué tengo que esconderme, qué tenemos que esconder tú y yo? ¿No es hermoso todo esto, no tenemos tú y yo, padre, que hacerlo hermoso?" (Droguett, 2016: 25). El narrador, en cambio, y padre adoptivo del niño, afirma sin mucha convicción que "la naturaleza no produce nada superfluo" (2016:25). Conforme el narrador escribe sus memorias va recreando la belleza del niño:

Desde luego, no era un muchacho deforme, no, su cuerpo era firme y esbelto, delgado y duro, casi atlético, a pesar de lo mal que se alimentaba y sus piernas eran un par de soberbias piernas de perro, robustas y orgullosas, enhiestas y casi fieras y en la cintura se juntaban de un modo tan natural que parecía que él había nacido de una generación muy antigua y refinada, de una maravillosa familia de seres humanos con patas de perro (Droguett, 2016:39).

La gente, sin embargo, lo mira con desconfianza, con asco, con curiosidad y hasta con furia; pero también surge la idea de explotar su rareza con fines económicos: "le dijo que era un hermoso desgraciado, un maravilloso monstruo, un magnífico escándalo de la naturaleza y que eso que parecía una desgracia podía ser la suerte y la fortuna de una familia en la miseria" (Droguett, 2016:35). Esta visión mercantil 
del diferente cristaliza en la exhibición lastimera a la que lo somete el padre para obtener dinero.

La novela se va construyendo entre el contraste de la reprobación ajena, la tristeza del narrador y la decisión de Bobi de defender su yo, mitad humano, mitad perro, casi con orgullo. $\mathrm{Y}$ en esta contradicción de percepciones, el propio relato surge atravesado por la confrontación en todos los niveles de la composición: escribir para olvidar, cuando la escritura es fuente para la preservación de la memoria; la fuerza de la naturaleza con su propia lógica frente a los valores sociales que rechazan y niegan a una criatura producto de lo natural. Lo humano ante lo animal. En este nivel, la novela se convierte en una insinuada recuperación crítica de la pugna entre la barbarie y la modernidad anhelada que tanto ocupó a los novelistas decimonónicos de América Latina y que ahora adquiere el signo contrario: la barbarie está en los que niegan la belleza natural por sus prejuicios de lo que debe ser normal y civilizado.

La composición de Patas de perro en el espíritu de la estética de lo grotesco se revela en esta heterogeneidad que alimenta su trama y su estilo. $Y$ a este respecto vale la pena anotar la peculiaridad del aliento desbordado con la que está escrita, en una incesante profusión discursiva que dilata las pausas en párrafos sumamente extensos: obsérvese, por ejemplo, cómo todo el primer capítulo de cinco cuartillas es un solo párrafo. Estilo desmesurado como todo lo que tiene que ver con lo grotesco. Pero hay otros rasgos que se conectan con la peculiar construcción de este estilo, algo que ya había observado Ariel Dorfman:

También el recuerdo y el olvido, otra forma de lo híbrido, otra manera de ser Bobi, se expresan de diferentes modos. Por ejemplo, pasado y presente sufren un continuo desplazamiento, se yuxtaponen en una oración, una marea de recuerdo y presencia. También lo que dice el narrador y lo que dicen los personajes está nivelado, se mueve de uno a otro sin mediatización, a veces no se sabe quién habla (Dorfman, 1970: 183). ${ }^{14}$

Y, en efecto, el mundo lingüístico de Bobi invade constantemente la enunciación del narrador $y$ hasta parecen fusionarse; la voz narradora/autoral no se preocupa por deslindar su discurso del de su personaje para llegar a construir esta habla a dos voces. Pero no es la única voz que se cuela en los resquicios de la del relato, son las acusaciones de los otros también, y el narrador contrasta siempre lo que oye con lo

14 Teobaldo A. Noriega hace un análisis de los niveles narrativos y de la temporalidad del relato, por lo que remito al lector interesado a su artículo, aunque se quede en el plano meramente de lo técnico (Noriega, 1982: 269-279). 
que ve, hasta llegar a la irrealidad del mundo, en un constante no saber qué pasa, si de verdad ocurrieron las cosas: "A ratos me parecía que no habíamos hablado en absoluto el teniente y yo, que habíamos estado sentados uno frente al otro desde muy temprano mientras afuera estaba el sol..." (Droguett, 2016: 12I). En otras palabras, una historia como la que está luchando por reconstruir no puede ser contada al modo tradicional con un narrador que sepa con certeza todo y que distribuya y deslinde con toda claridad su mundo del mundo de los otros. $Y$ es que él mismo no sabe dónde está, él no pertenece al horizonte del niño-perro, pero tampoco a las valoraciones enjuiciadoras de los demás. Él no puede, en realidad, entrar nunca en el mundo de Bobi, siempre se quedará afuera, rondando alrededor del niño, con sus buenas intenciones.

Es muy significativo de la incertidumbre que atravesará toda la historia el epígrafe con el que se abre el relato: “...y ahora dicen algunos que yo me estoy volviendo loco $y$ que el niño jamás existió. Los padres de Bobi se rien de mí cuando les converso y un día hasta me mostraron la libreta de matrimonio donde constan todos sus hijos, muertos $y$ vivos, pero ningún monstruo, bramó el borracho con miedo y odio." (Droguett, 2016ः 2I. Cursivas en el original). Así, aunque el narrador se afirme en la indudable existencia de Bobi, queda abierta la fisura de que toda esta historia es producto de la locura que no puede menos que engendrar un monstruo grotesco. ${ }^{15}$ Pero la pregunta queda flotando en el aire: ¿para qué inventar un híbrido que tantos sinsabores vivió e hizo pasar a los demás? ¿ Un trasunto de la imaginación tradicional que ya no tiene cabida en la modernidad?

Los nexos de esta novela tan abierta y declaradamente producto de la escritura con el mundo de la oralidad popular quedan revelados en el cuento intercalado del pollo que no alcanzó a nacer entero, sino que solo fue mitad pollo. Este relato se cuenta en varias comunidades del mundo hispánico; es una leyenda que se remite a la antigüedad, justo antes de la modernidad: "antes de que existieran tenientes y médicos y abogados, de otro modo no lo habrían dejado tranquilo" (Droguett, 2016: 209-210). Y en esa antigua leyenda de la mitad de un ser viviente puede prefigurarse la existencia de un ser híbrido, también bello a su manera, "parece dulce, tímido, agradable, lindos ojos tiene, es decir tiene un lindo ojo, un solo ojito, señora, una sola ala, una sola pata, ¿sabe?, y abi anda arrastrando la pluma, orondo y suficiente, como si fuera un pollo entero" (Droguett, 2016: 212. Cursivas en el original). Así se hermana

15 Para un estudio más detenido sobre la importancia de la locura en la estética grotesca hispanoamericana, véase mi libro Locura e imaginación. Grotesco en la literatura bispanoamericana (Munguía, 2019). 
la escritura culta, melancólica y solitaria, con el relato oral forjado por la imaginación de pueblos que no ponían trabas a las posibilidades de múltiples existencias.

Ahora bien, no pretendo afirmar que toda la novela hispanoamericana contemporánea se haya compuesto bajo el signo de lo grotesco, solo quiero destacar la importancia y la necesidad de recuperar las huellas de la imaginación ancestral, que pervive en las culturas orales del continente y que han sido una fuente inagotable en la creación de la literatura culta, si queremos entender el proceso de conformación y la propuesta artística que anida en estas obras. La estética de lo grotesco, entendida en el sentido de una visión de profundas raíces populares, sigue siendo un manantial formidable para la creación de nuevas imágenes artísticas. Las posibilidades del patetismo y del didactismo han sido agotadas. También me parece que resulta un tanto improbable la creación de mundos desde la comicidad alegre y festiva si tenemos en cuenta que la narrativa ha cumplido y seguramente seguirá cumpliendo el papel de conciencia crítica de los valores dados por sentado en la sociedad.

Locos, burladores, pícaros renovados, bufones de hoy, seres híbridos, monstruosos, toman la palabra en la literatura, se resisten a ser domesticados, bien pensantes y acicalados. Ellos le están dando el perfil a la escritura actual a contracorriente de los valores imperantes en la sociedad humorística banal de nuestros días. Podemos esperarlo todo de esta literatura que no ha pactado y que tal vez ría de manera demasiado incorrecta y escandalosa para el gusto de las decentes clases medianamente educadas.

\section{Referencias bibliográficas}

Arguedas, José María

1992 El zorro de arriba y el zorro de abajo, México, Archivos Unesco. Bajtín, Mijail

I988 La cultura popular en la Edad Media y en el Renacimiento. El contexto de Francois Rabelais, Madrid, Alianza Editorial.

Beltrán Almería, Luis

I995 "La revuelta del futuro: mito e historia en Cien años de soledad", Cuadernos bispanoamericanos, 535, pp. 23-38.

Cornejo Polar, Antonio

I999 "Para una teoría literaria hispanoamericana: a veinte años de un debate decisivo", Revista de crítica literaria latinoamericana, 50, pp. 9-I2. DoI: http://dx.doi.org/10.2307/4531050 
Dorfman, Ariel

1970 "El patas de perro no es tranquilidad para mañana", Revista chilena de literatura, 2/3, pp. 167-197.

Droguett, Carlos

2016 Patas de perro, Barcelona, Malpaso.

García-Bedoya, Carlos

2018 "Para historiar la heterogeneidad. Con algunas calas sobre el proceso literario peruano del siglo xıx., en Liliana Weinberg y Rodrigo García de la Sienra (coords.), Historia comparada de las Américas. Siglo XIX. Tiempo de letras, México, unam, pp. 57-84.

García Márquez, Gabriel

2007 Cien años de soledad, Bogotá, Real Academia Española.

González Echevarría, Roberto

201 Mito y archivo. Una teoría de la narrativa latinoamericana, México, Fondo de Cultura Económica.

González Echevarría, Roberto

2004 “The Making of the Latin American Novel”, en Mario J. Valdés y Djelal Kadir (eds.), Literary Cultures of Latin America. A Comparative History, vol. II, Oxford University Press, pp. 289-305.

González Echevarría, Roberto

2006 "Breve historia de la historia de la literatura hispanoamericana", en Roberto González Echevarría y Enrique Pupo-Walker (eds.), Historia de la literatura bispanoamericana I (Del descubrimiento al Modernismo), Madrid, Gredos, pp. 35-59.

Kushner, Eva

1994 “Articulación histórica de la literatura”, en Françoise Perus (comp.), Historia y literatura, México, Instituto Mora, pp. 165-187.

Meruane, Lina 2016 "Prólogo", Carlos Droguett, Patas de perro, Barcelona, Malpaso.

Munguía Zatarain, Martha Elena

2019 Locura e imaginación. Grotesco en la literatura hispanoamericana, México, Universidad Veracruzana-Ficticia Editorial.

Munguía Zatarain, Martha Elena

2012 La risa en la literatura mexicana (Apuntes de poética), Madrid/ México, Iberoamericana Vervuert/Bonilla Artigas.

Noriega, Teobaldo A. 
I982 "Narrador, tiempo y realidad en Patas de perro de Carlos Droguetti", Revista Canadiense de Estudios Hispánicos, 6(2), pp. 269-279.

Pacheco, Carlos

I992 La comarca oral, Caracas, La Casa de Bello.

Perus, Françoise

1998 De selvas y selváticos. Ficción autobiográfica y poética narrativa en Jorge Isaacs y José Eustasio Rivera, Santafé de Bogotá, Plaza \& Janés/ Universidad Nacional de Colombia/ Universidad de los Andes.

Pozuelo Yvancos, José María

I993 Poética de la ficción, Madrid, Síntesis.

Rama, Ángel

1991 La narrativa de Gabriel García Márquez. Edificación de un arte nacional popular, Bogotá, Instituto Colombiano de Cultura.

Schmidt-Welle, Friedhelm

2018 "Algunas hipótesis para una renovación de la historiografía literaria latinoamericana del siglo xix", en Liliana Weinberg y Rodrigo García de la Sienra (coords.), Historia comparada de las Américas. Siglo XIX. Tiempo de letras, México, unam, pp. IOI-II7.

Valdés, Mario J.

2004 "Introduction. Beyond Literary History", en Mario J. Valdés y Djelal Kadir (eds.), Literary Cultures of Latin America. A Comparative History, vol. I, Oxford, University Press, pp. xvii-xxv.

Martha Elena Munguía Zatarain

Doctora en Literatura Hispánica por El Colegio de México. Trabaja como investigadora en la Universidad Veracruzana, México. Su línea de investigación actual es Poética histórica en Hispánoamérica y ha coordinado el proyecto colectivo "Manifestaciones de la risa en la literatura hispanoamericana". Es autora de los libros Locura e imaginación. Grotesco en la literatura bispanoamericana (2019); La risa en la literatura mexicana (apuntes de poética) (2012); Elementos de poética histórica. El cuento hispanoamericano (2002). Coordinó con Luis Beltrán y Claudia Gidi el libro Risa y géneros menores (20I7). Ha colaborado con capítulos en varios libros colectivos y artículos en diversas revistas de la especialidad. 
Citar como: Martha Elena Munguía Zatarain (2020),"Grotesco: un hito en la travesía de la novela hispanoamericana”, Iztapalapa. Revista de Ciencias Sociales y Humanidades, núm. 89, año 4I, julio-diciembre de 2020, ISSN: 2007-9176; pp.67-88. Disponible en <http://revistaiztapalapa.izt.uam.mx/ index.php/izt/issue/archive $>$. 